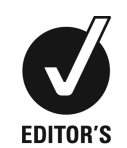

CHOICE

${ }^{1}$ Department of Oral Medicine and Oral Radiology, Rajas Dental College and Hospital, Tirunelvelli, Tamil Nadu, India ${ }^{2}$ Maxillo Facial, Doctor Kamalkanadasan Dental Clinic Chennai, Tamil Nadu, India ${ }^{3}$ Dental Department, Jeba Dental Clinic, Chennai, Tamil Nadu, India

\section{Correspondence to}

Dr M Hari Kumar,

drhari.omrd@gmail.com

Accepted 6 July 2015
CrossMark

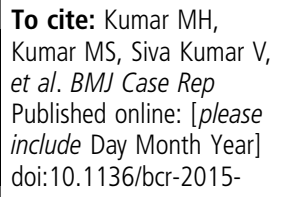

\title{
An adult with 3-M syndrome
}

\author{
M Hari Kumar, ${ }^{1}$ M Siva Kumar, ${ }^{2}$ Vishalakshi Siva Kumar, ${ }^{2}$ Sabitha Hari Kumar ${ }^{3}$
}

\section{DESCRIPTION}

3-M syndrome is a rare autosomal recessive disorder characterised by short stature, dysmorphic facial features and skeletal abnormalities. Individuals with 3-M syndrome have a recognisable pattern of features including a triangular face with

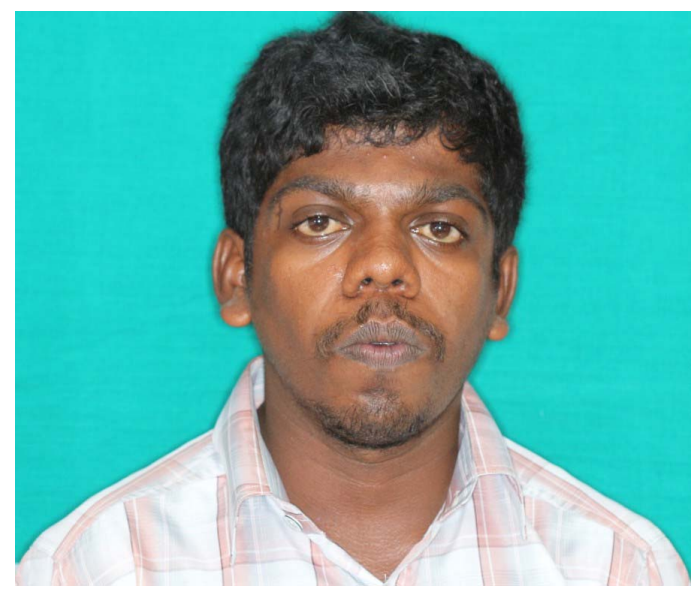

Figure 1 Triangular-shaped face with a prominent mouth, midface hypoplasia and malar flattening. pointed chin, large ears, full eyebrows, an upturned nose with a fleshy tip, a long philtrum, and a prominent mouth with full lips. ${ }^{1}$ In the spine, especially in the lumbar region, the vertebral bodies are tall and reduced in their anteroposterior and transverse diameters. The skeletal findings become more apparent with increasing age. ${ }^{2}$

Mutations in the CUL7, OBSL1 and CCDC8 genes have been associated with the condition. CUL7 is involved in chondrocyte growth and proliferation, and it is proposed that in 3-M syndrome, reduced cell mitosis during the early gestation period could be the cause of retarded growth. In particular, these mutations disrupt the ability of the protein cullin-7 to facilitate assemblage of the ubiquitin-proteasome complex involved in protein degradation. This finding supports the theory that impaired ubiquitination may have a role in the pathogenesis of intrauterine growth retardation (IUGR) in humans. ${ }^{1}$

The physical findings of several entities such as Silver-Russell syndrome (SRS) and Mulibrey nanism resemble those of 3-M syndrome. SRS has many similarities with 3-M syndrome, including IUGR, short stature, triangular face, relatively large skull,

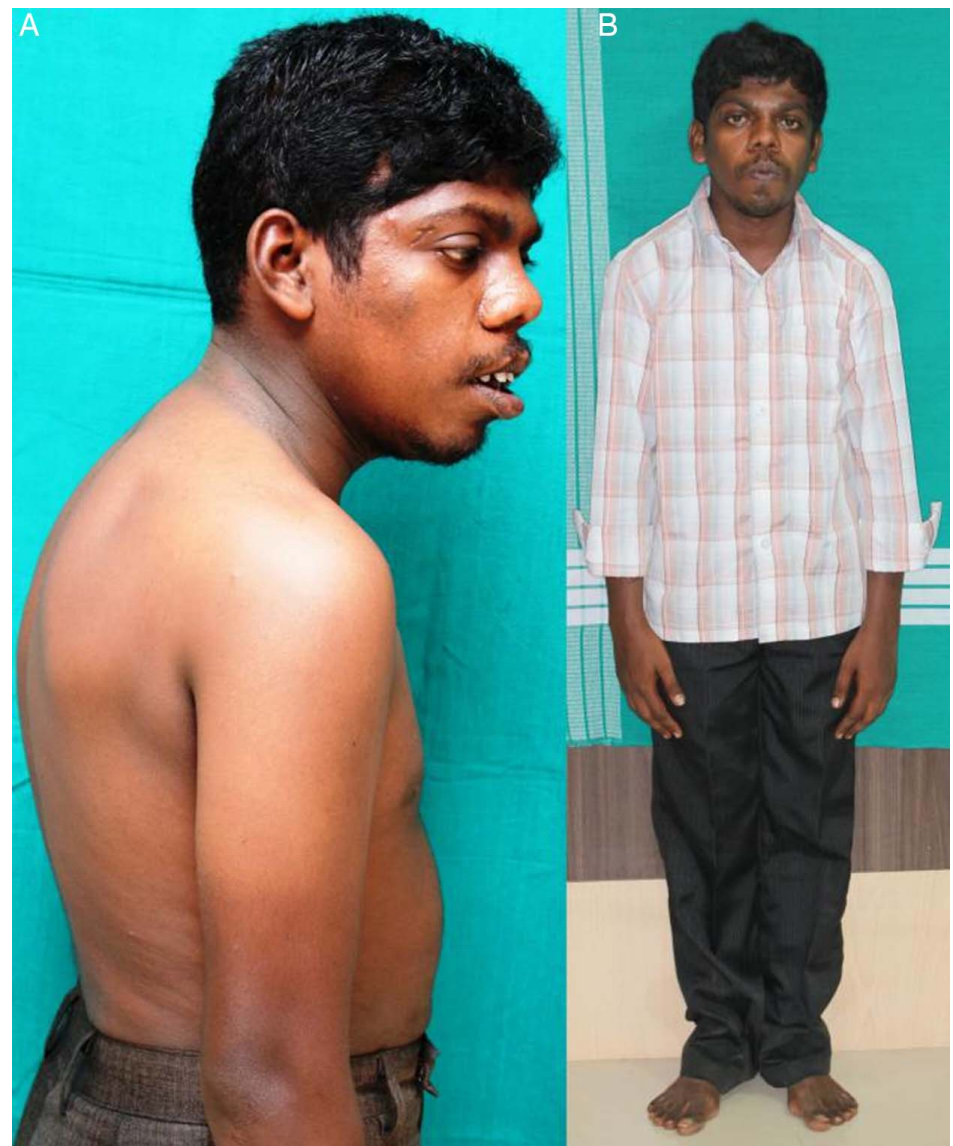

Figure 2 (A) Prominent trapezius with marked hyperlordosis. (B) Frontal view of the patient. 


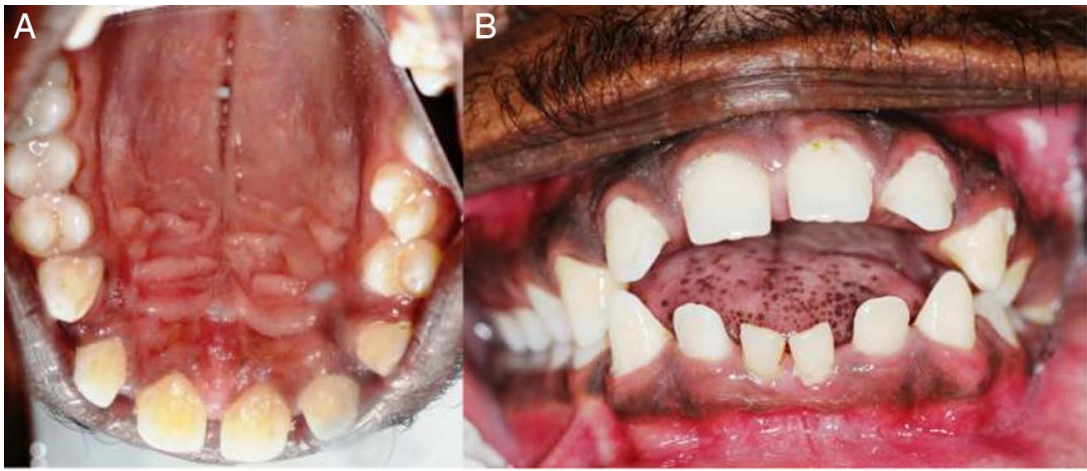

Figure 3 (A) Intraoral examination showing high arched palate. (B) Skeletal anterior open bite.

asymmetry of body or limbs, and clinodactyly. Mild mental retardation also can be found in patients with SRS. ${ }^{3}$

In this case, a 23-year-old male was diagnosed with 3-M syndrome in the oral medicine department during a routine dental visit. He had a triangular-shaped face with a prominent mouth, thick patulous lips, long philtrum, pointed chin, broad, fleshy nose with anteverted nostrils, and curvilinear eyebrows. He also exhibited mild midface hypoplasia with malar flattening and downward slanting eyes (figure 1). He had prominent trapezius muscles, marked hyperlordosis (figure 2A) and was $125 \mathrm{~cm}$ in height (figure 2B).

The patient had normal intelligence. His father had similar features. Intraoral examination revealed a high arched palate (figure $3 \mathrm{~A}$ ) with a skeletal anterior open bite (figure 3B).

Complete blood count, biochemical analysis and thyroid function tests were in the normal range. Lumbar spinal radiography

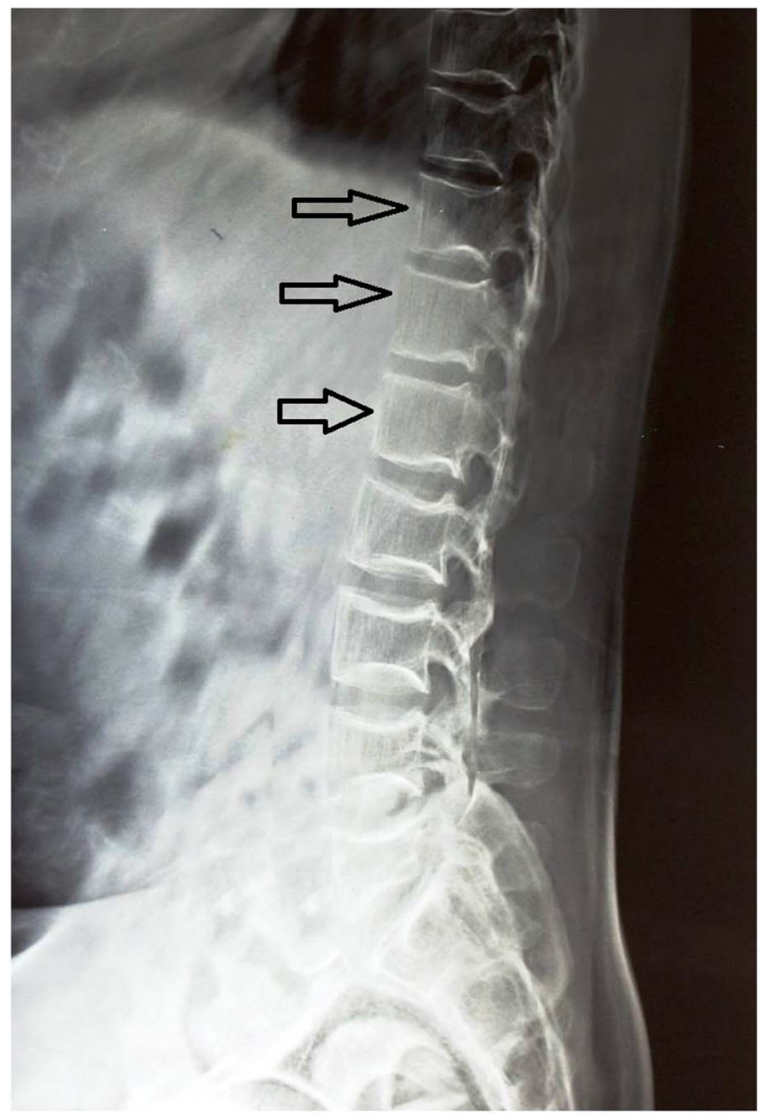

Figure 4 Lumbar spinal radiograph showing relatively tall, narrow vertebral bodies indicated with black open arrows. showed relatively tall, narrow vertebral bodies (figure 4). The lateral cephalometric radiograph of this patient showed the direction of growth was predominantly vertical (59\%) and the lower gonial angle was increased $\left(86^{\circ}\right)$. The upper incisors were far ahead $(+22 \mathrm{~mm})$ of the NPog line (figure 5). Sassouni analysis revealed that the maxilla was rotated downwards posteriorly and the mandible was rotated downwards anteriorly. This abnormal rotation of the jaw resulted in a skeletal open bite (figure 6). Phased orthodontic treatment and orthognathic surgery was recommended; the surgery plan includes bimaxillary Le Fort I osteotomy with anterior maxillary osteotomy and bilateral sagittal split osteotomy.

However, the patient's parents were upset about the diagnosis of 3-M syndrome and unable to accept the suggested remedies. Moreover, they were unaware of the presence of a genetic disorder, which was accidentally diagnosed during a routine dental visit. Even after psychological counselling they were reluctant to undergoing molecular genetic testing. Hence, it is advisable to provide ample time for the parents of patients to come to terms with the diagnosis and accept further timely investigation.

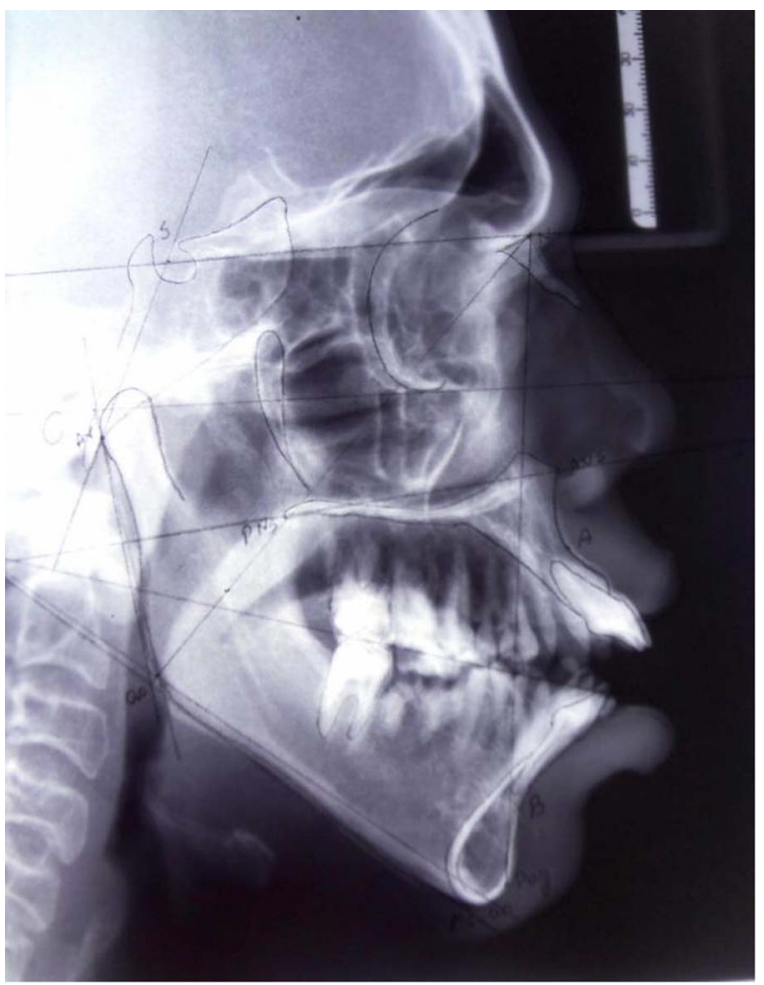

Figure 5 Cephalometric radiograph showing increased lower gonial angle $\left(86^{\circ}\right)$. 


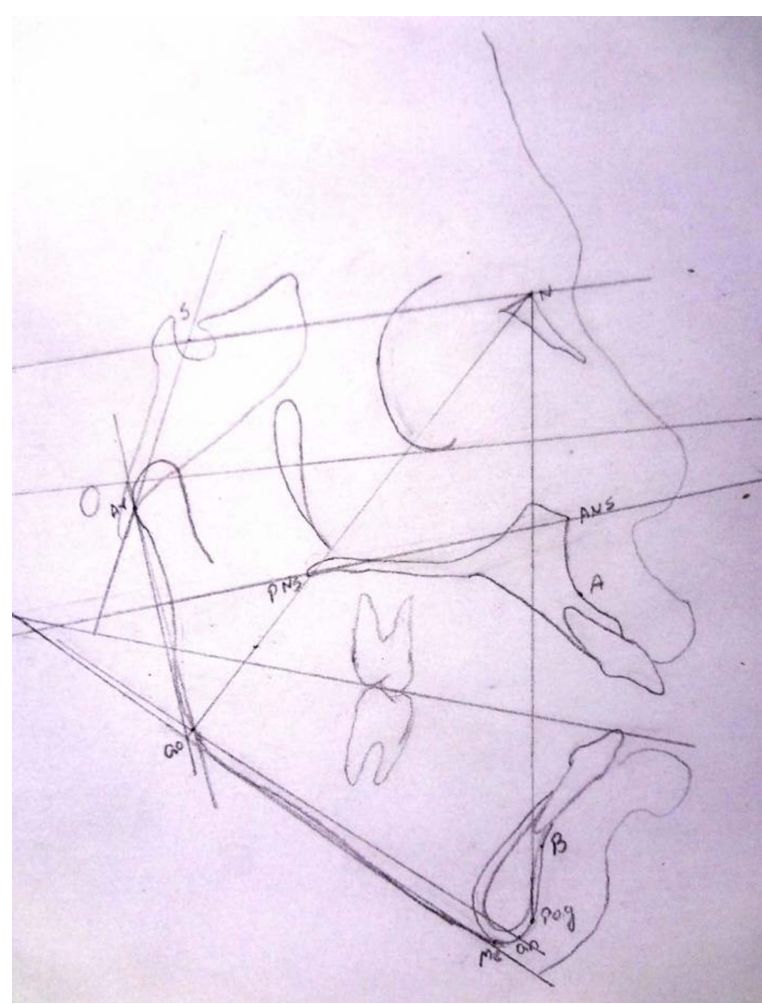

Figure 6 Sassouni analysis showing the maxilla rotated downwards posteriorly and the mandible rotated downwards anteriorly.

\section{Learning points}

- 3-M syndrome is a rare autosomal recessive disorder caused by mutations in the CUL7, OBSL1 and CCDC8 genes.

- The syndrome is characterised by low birth weight and proportionate dwarfism, while a skeletal survey reveals characteristic features including slender, long bones and ribs, particularly during childhood.

- If 3-M syndrome is suspected, evaluation and counselling by a medical genetics team is recommended to establish the diagnosis, guide care management, and provide reproductive counselling for the patient and their family.

Contributors MHK, MSK, VSK, SHK: diagnosis of the patient and concept of the paper; MHK, MSK, VSK: acquisition of data; MHK, MSK, SHK: drafting the article; MHK, MSK, VSK, SHK: revision and final approval of the article.

Competing interests None declared.

\section{Patient consent Obtained.}

Provenance and peer review Not commissioned; externally peer reviewed.

\section{REFERENCES}

1 Meazza C, Lausch E, Pagani S, et al. 3-M syndrome associated with growth hormone deficiency: 18 year follow-up of a patient. Ital J Pediatr 2013;39:21.

2 Winter RM, Baraitser M, Grant DB, et al. The 3-M syndrome. J Med Genet 1984;21:124-8.

3 Guven A, Cebeci AN. 3-M syndrome: a report of four cases in two families. J Clin Res Pediatr Endocrinol 2011;3:154-9.

Copyright 2015 BMJ Publishing Group. All rights reserved. For permission to reuse any of this content visit http://group.bmj.com/group/rights-licensing/permissions.

BMJ Case Report Fellows may re-use this article for personal use and teaching without any further permission.

Become a Fellow of BMJ Case Reports today and you can:

- Submit as many cases as you like

- Enjoy fast sympathetic peer review and rapid publication of accepted articles

- Access all the published articles

- Re-use any of the published material for personal use and teaching without further permission

For information on Institutional Fellowships contact consortiasales@bmjgroup.com

Visit casereports.bmj.com for more articles like this and to become a Fellow 